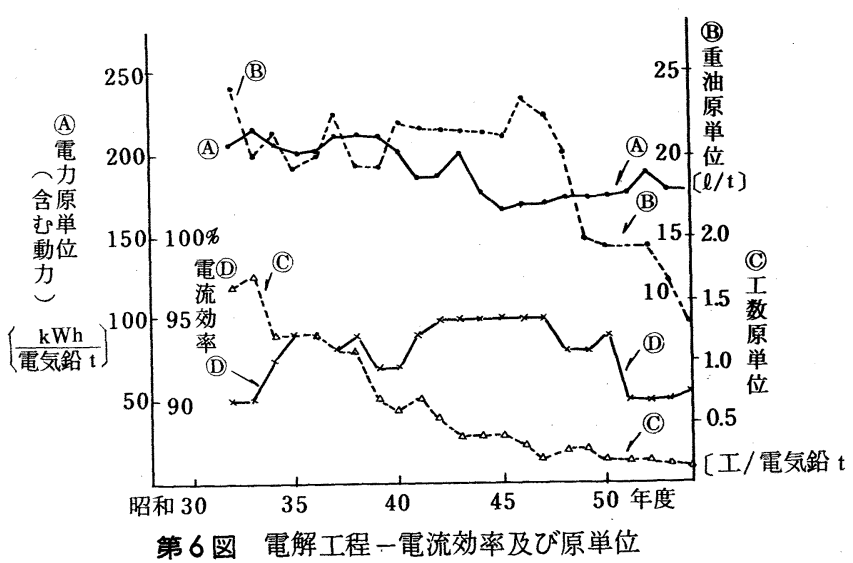

トは鉄置換法を採用している。鉄屑無添加の場合, $\mathrm{Pb}$ は $20 \%$ 弱 まで上るが，現法では $10 \%$ 内外である。

$\mathrm{Ag}$ はある程度までは $\mathrm{P} b$ 品位に比例し, 現状 $600 \mathrm{~g} / \mathrm{t}$ 程度とな つている。

スパイス中の $\mathrm{Pb}, \mathrm{Ag}$ については, 最近の阿座上教授の報文を 参考にして, 鉄屑添加による低減法を, 操業規模でトレースして おり，近々結果をまとめる予定である。

\section{$3 \cdot 5$ 電錬工程}

電解工場の省力化については，逐次実施してきたが，抜本的に は, 電槽の再配列化等, 諸設備の配置そのものの見直しが必要で ある。この問題は, 電解だけに限らず, 全所的な問題ではあるが, 容易でなく，現有設備の中でできるだけの創意工夫で対処してゆ かねばならないと考えている。
電力原単位の低滅についても, 電流効率の向上及び電解液抵抗 の低減等で努力してきた。すなわち，53年 B F部門でのアノード 立型自動鋳造方式の採用に当つて実施した脱 $\mathrm{Cu}$ の強化及び, 品 質の安定化で, ショート率が一段と低下したこと, さらに浄液 ( 脱 $\mathrm{Pb}$ ) 電解における極板の選択等で $\mathrm{Pb}$ イオンすなわち遊離酸の コントロールで, 電解電圧を低位に保つこと, 等実施してきたが, なかなか $140 \mathrm{kWh} / \mathrm{t}$ 台の壁が破れなかつた。

最近もう一つの管理要因である極板, 特に重量の軽いスターテ ヘングシート関係の接触抵抗の低隇化に努め, ほぼ $130 \mathrm{kWh} / \mathrm{t}$ 台の原単位 (電解電力) 確保の見通しを得ている。

因みにこの場合の電流効率は $95 \%$ アップ，スクラップ率約 28 \%である。

なお操業データの推移を，第 1 図〜第 6 図に示す。

$$
\text { 4. 結泣 }
$$

過去 10 年間を回顧するに, 原料の変動や, 環境をはじめ公害防 止規制の強化等に，よく対応してきたという自負を持つ反面，エ ネルギーコスト等, 諸物価の高騰については，まだまだ対処すべ き数多くの問題を抱えている。また近年, 鉛製鍊の分野にも K I $\mathrm{VCET}$ 法等, 直接製鍊の操業規模での工業化テストや導入企画等, 積極的に試みられてきている。

原料の複雑化，エネルギーコストの高騰等によつて拍車がかけ られ，近い将来，主流を占めることになるかも知れない。

かかる状況下ではあるが，当面のわれわれとしては，現存法の 長所を生かし, 短所を改め, 厳しい国際競争力に打ち勝つ手段に, 創意工夫をもつて対処してゆく所存である。

\title{
Lead Smelting and Refining at Chigirishima
}

by Teruo YAMAKITA

The Chigirishima Smelter of Toho Zinc Co., Ltd. is located on a small island of about $90,000 \mathrm{~m}^{2}$ situated in the National Park of the Inland Sea. This smelter is an independent custom lead smelter and its operation was started in 1951. At present, this smelter produces 6,000 tons/month of electrolytic lead. The main processes are as follows:
(1) Updraft sintering
(2) Blast furnace smelting
(3) Bullion drossing
(4) Electrolytic refining
(5) Slime treatment.

\section{〔2-14〕 彦島製棟所における亜鉊電解10 年の歩み}

\section{1. 緒}

三井金属鉱業(株)彦島製煉所は，大正 4 年水平レトルト法によ る蒸留覀鉛製造を開始し，戦後に至つたが公害防止，作業環境の 改善, 生産性の向上を目的として昭和 42 年に電解工場へのリプレ 一ス方針を決定した。

電解部門に先立ち，焙焼部門では従来のウェッジ多段焙燒炉お よび焼結炬に替りドル式流動焙焼炉が昭和 43 年 4 月より稼動を開 始した。電解工場は昭和 44 年 7 月着工, 昭和 45 年 11 月操業を開 始し, 一方水平レトルト炉は順次火をおとし昭和 46 年 7 月を最後 に姿を消した。

このようにして彦島製煉所は新鋭の臨海買鉱亜鉛電解製鍊所と

1. 正会員 三井金属鉱業株式会社三池製煉所長
鳥 越 隆 -1

してスタートしたが, 昭和 48 年のオイルショックにより亜鉛地金 需要は低迷して以来低操業度のやむなきに至つている。

しかし技術面においては省エネルギー,コスト低下対策に取組 み, 種々の設備, 操業方法の改善を行なつてきている。

なお，第 2 図には過去 10 年間の亜鉛生産量推移を示す。

\section{2. 焙焼，硫酸部門}

焙焼, 硫酸工場の操業系統図を第 3 図に, その主要設備を第 1 表に，精鉣および焼鉣の分析值例を第 2 表に示す。

$2 \cdot 1$ 原料受入，貯鉱

原料精鉱の大半は外国鉱を使用し, 昭和 47 年 9 月完成した $50,000 \mathrm{t}$ バースより陸揚げされる。アンローダは $800 \mathrm{t} / \mathrm{h} の$ 能 力で完全防鹿式である。昭和 51 年 5 月には $40,000 \mathrm{t}$ 貯鉱舎が 


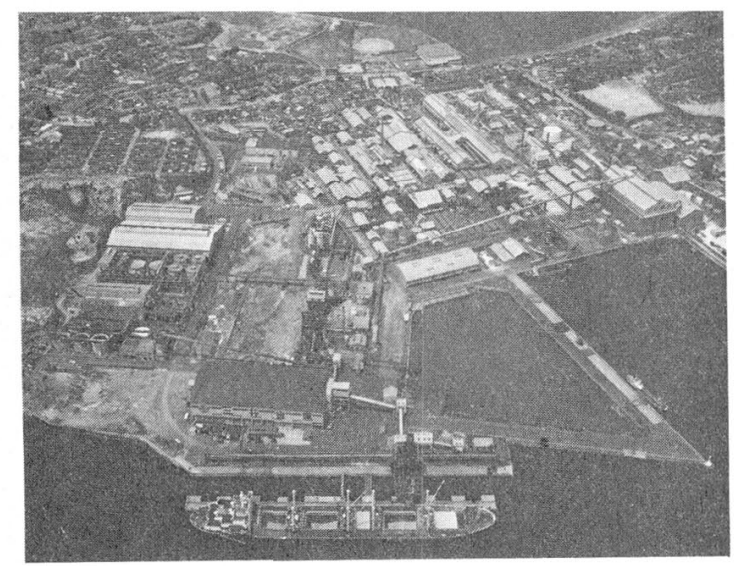

第1図彦島製煉所全景

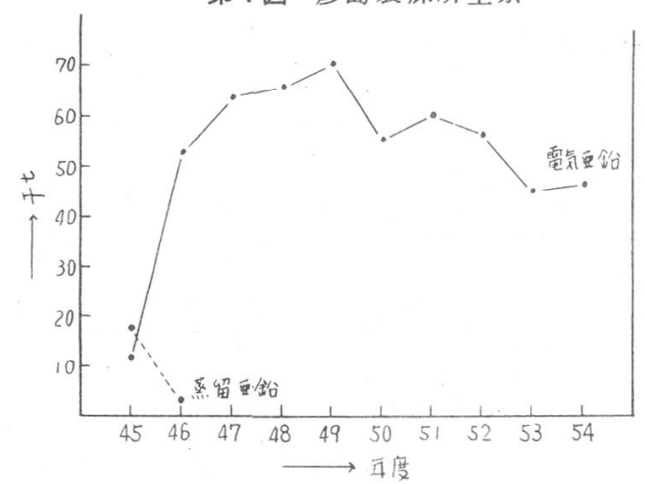

第2図 亜鉛生産量の推移

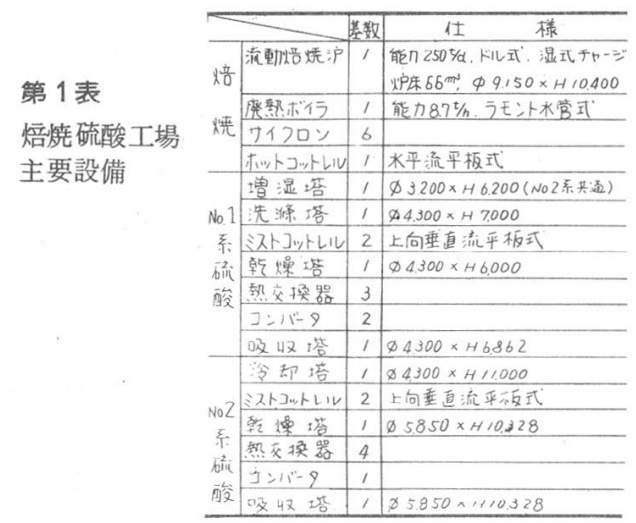

第 2 表 精鉱焼鉱の分析值例 (\%)

\begin{tabular}{|c|c|c|c|c|c|c|c|}
\hline \multicolumn{2}{|c|}{$r$} & $Z_{n}$ & $\mathrm{~Pb}$ & $\mathrm{~cd}$ & $\mathrm{Cu}$ & $\overline{\mathrm{He}}$ & $S$ \\
\hline \multirow{3}{*}{ 精 } & 外国鉱 $A$ & 51.4 & 0.6 & 0.27 & 0.72 & 8.29 & 312 \\
\hline & & 50.7 & 1.58 & 0.07 & 1.05 & 10.68 & 32.0 \\
\hline & $c$ & 52.4 & 0.74 & 0.18 & 011 & 1050 & 31.8 \\
\hline \multirow[t]{2}{*}{ 鉱 } & 国内鉱 $A$ & 55.3 & 0.33 & 0.33 & 0.08 & 7.17 & 31.7 \\
\hline & $B$ & 51.1 & 0.38 & 0.28 & 0.12 & 10.28 & 30.8 \\
\hline \multicolumn{2}{|c|}{ 焼 } & 59.1 & 0.72 & 0.24 & 0.54 & 0.75 & 1.8 \\
\hline
\end{tabular}

完成して，アンローダ，貯鉱舎，焙焼炉間の運搬を全てベルトコ ンベャ方式として鉱石の受入，払出しの大幅な合理化を行なつた。

\section{$2 \cdot 2$ 焙㸁炉}

焙焼炬は湿式チャージのドル式流動焙焼炉で，その能力は精鉱 250 t/d であり, 亜鉛電解工場の能力に比べ小さいので不足分の 焼鉱は三池製煉所から船で搬入される。

以下に哣焼炬関係の特長と改善点を述べる。

（1）硫酸亜鉛溶液による精鉱のスラリー化後述のように当 所の硫酸工場排ガス処理は酸化亜鉛法であり，ここで発生する硫 酸亜鉛溶液で精鉱のスラリー化を行なつている。

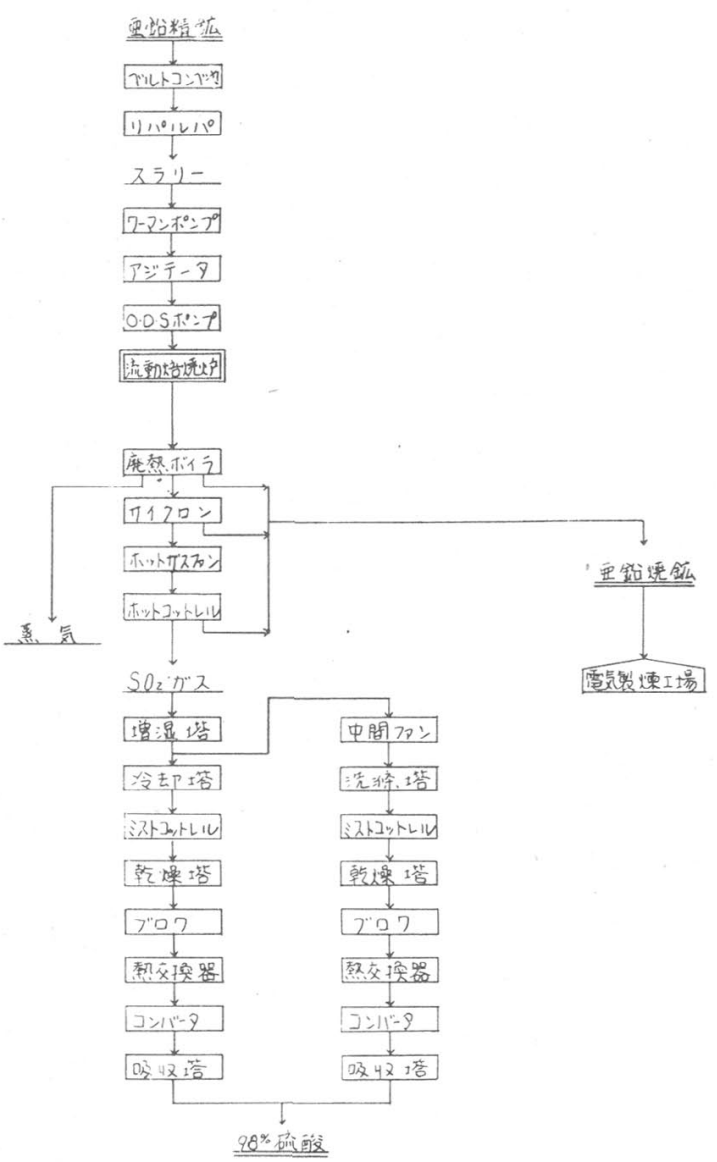

第 3 図 焙焼硫酸工場操業系統図

（2）溶鋳ドロスの焙焼炬供用（昭和 50 年 4 月以降）電気亜 鉛の溶鋳工程で発生する電気炉ドロスを焙焼炉に絽返し供用して 亜鉛採収率向上を計つている。

（3）ふる以上焼鉱の絽返し供用 (昭和 53 年 3 月以降) 焼鉱 をふるい機にかけたふるい上焼鉱 $(+3 \mathrm{~mm})$ は焙焼炬へ絽返すこ とにより残留Sは $0.2 \%$ 低下した。

(4) フルオシールの廃熱回収 (昭和 52 年 3 月以降) フルオ シールに水冷ジャケットを取付けて, 予熱された温水をラモント ボイラーに給水することにより廃熱回収を行なつた。この結果蒸 気発生量が精鉱 $\mathrm{t}$ 当り $0.07 \mathrm{t}$ 増加した。

（5）入気ブロワの蒸気タービン化 (昭和 54 年 7 月以降) 入 気ブロワの動力源として $320 \mathrm{~kW}$ の電動機を使用していたが, 蒸 気タービン化して約 $6,300 \mathrm{kWh} / \mathrm{d}$ の省電力が可能となつた。

（6）その他の省エネルギー改善項目

a）輸送ポンプの変更：アジテータへのスラリー輸送をOD S ポンプからワーマンポンブに変更した。

b) カルサインクーラの廃止：フルオシールに水冷ジャケット を取付けたことによりカルサインクーラの廃止が可能となつた。

c）ホットガスフォンの流体継手化：ホットガスフォンの流量 調節をダンパ方式から流体継手による方式に変更した。

以上のような改善により焙焼部門での電力使用量は, 従来の 80 $\mathrm{kWh} /$ 焼鉱 $\mathrm{t}$ から $35 \mathrm{kWh} /$ 焼鉱 $\mathrm{t}$ 一と大幅に減少した。

\section{$2 \cdot 3$ 硫酸工場}

硫酸工場はNo.1系, No.2系と 2 セットあり, No.1 系は昭和 16 年に建設された旧工場で，No.2 系は流動焙焼炬とともに昭和 43 年に建設された新工場である。 
焙焼炬からの $\mathrm{SO}_{2}$ ガスは增湿塔を出た所でNo.1系とNo.2系へ 分配して送られる。増湿塔以降のガス道はNo.1系では鉛製であ つたが No.2 系ではFRP を採用し，No.1系でも老朽力所は逐次 F R P に更新中である。

以下，硫酸工場の特長，改善点を述べる。

（1）酸化亚鉛法による排ガス処理硫酸工場排ガスはスプ レー塔で焼鉱スラリーと接触させることにより $\mathrm{SO}_{2}$ を $\mathrm{ZnSO}_{3}$ と する。この $\mathrm{ZnSO}_{3}$ は分解槽に送られ，そこで濃 $\mathrm{H}_{2} \mathrm{SO}_{4}$ を加え ることにより, $\mathrm{ZnSO}_{4}$ 溶液と $\mathrm{SO}_{2}$ ガスに分解され, $\mathrm{ZnSO}_{4}$ 溶 液は前述のように精鉱調合液として使用される。発生する $\mathrm{SO}_{2}$ カ スは高濃度のため硫酸工場へ繰返される。

(2) メインブロワの $V \vee V F$ 制御 (昭和52年3月以降) メ インブロワはVVVF制御方式とし省電力を計つている。

\section{3. 溶解, 清浄部門}

溶解，清浄工程はともに完全な連続方式であり，工程制御用コ ンピュータを導入して計装化を計つた。

第 4 図には亜鉛電解工場全体の操業系統図を，また第 3 表には その主要設備を示す。

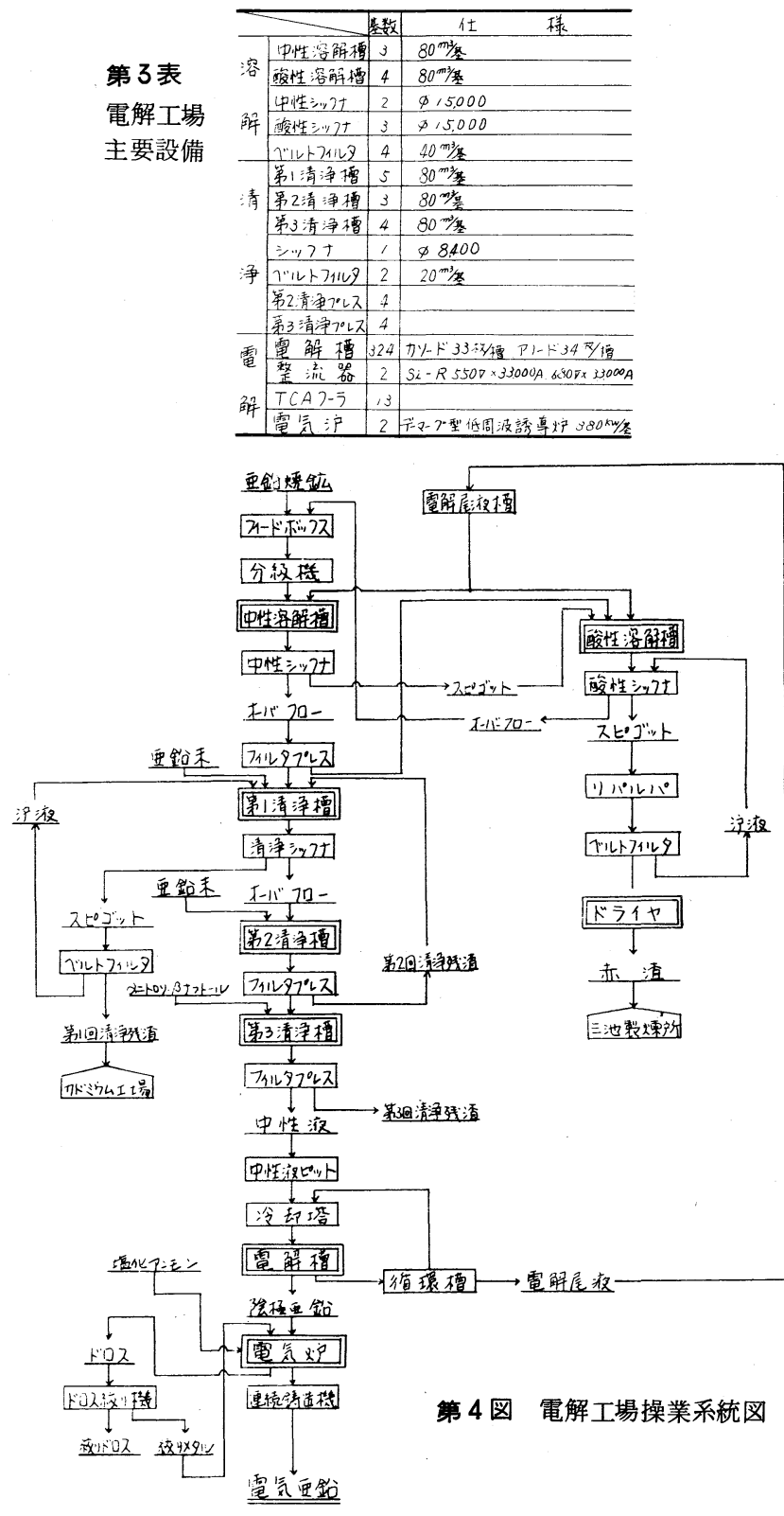

\section{$3 \cdot 1$ 溶解工程}

溶解工程の特長を以下に述べる。

（1）焼釷の湿式分級粉砕焼鉱は 2 基の貯鉱ビンに貯えら れた後，CFWで秤量切出され，フィードボックスにおいて酸性 シックナOF夜でスラリー化される。このスラリーはスパイラル 分級機により分級され，オーバーサイズは閉回路を形成する湿式 ボールミルで粉砕され，アンダーサイズは中性溶解槽へ送られる。

（2）連続複式溶解溶解方式は連続複式溶解法で中性溶解 槽 3 基, 酸性溶解槽 4 基からなる。槽間の移液はエヤーリフトで 行なつている。

$\mathrm{Fe}$ 酸化剂としで中性溶解槽には $\mathrm{KMnO}_{4}$ 溶液が添加される。 $\mathrm{pH}$ は電極の自動洗浄装置を備えた $\mathrm{pH}$ 計で連続測定され, コ ンピュータにインプットされて尾液の添加量が自動コントロール される。

（3）赤渣の連続向流洗浄 酸性溶解スラリーは直列 3 基の シックナに送られ向流洗浄される。最終シックナのスピゴットは ベルトフィルタで沪過され, 再度洗浄水でリパルプ後ベルトフィ ルタで沪過される。ケーキはロータリードライヤで水分 $20 \%$ ま で乾燥後, 船で三池製煉所へ送られる。

（4）アノード整備液供用による加鉄清浄後述のようにア ノードのマンガンクラストは硫酸第一鉄により化学的除去を行な つているが，鉄を多量に含む整備終了液を酸性溶解工程に供用し て As , S b , Ge 等不純物の加鉄清浄を行なつている。

$3 \cdot 2$ 清浄工程

清浄工程は亜鉛末による第 1 , 第 2 清浄工程, $\alpha$ 一ニトロソ $\beta$ 一ナフトールによる第 3 清浄工程からなる 3 段清浄法である。

第 4 表には溶解，清浄終了液の分析值例を示す。

（1） $\alpha$-ニトロソ $\beta$-ナフトールによるCo清浄 Co 除去

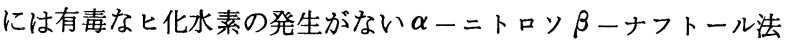
を採用している。反応槽は 4 槽からなり最終槽には残留 $\alpha$ 一 $=$ 卜 ロソ $\beta$ 一ナフトールを除去するため粉末活性炭を加える。

（2）CFWによる覀鉛末自動添加（昭和49年以降）清浄液 流量等の必要データをコンピュータにインプットすれば亜鉛末添 加量が計算され，この計算量をコントロールルームからC FWを リモートコントロールして添加させる。

（3）第 3 清浄工程の自動 $\mathrm{pH}$ コントロール (昭和49年以降) $\alpha$ ーニトロソ $\beta$-ナフトールによるCo 清浄では $\mathrm{pH}$ 管理が重要 となるため, 電極の自動洗浄機構を備えた $\mathrm{pH}$ 計で連続測定し, 尾液添加量を自動コントロールしている。

（4）第 1 清浄工程固液分離の連続化 (昭和 49 年 7 月以降)

従来, 第 1 清浄, 第 2 清浄, 第 3 清浄の各工程とも固液分離に はフィルタプレスを用いていたが, フィルタプレスは残渣除去に 多大の労力を要するため第 1 清浄工程の固液分離法の改善を行な つた。すなわち第 1 清浄工程終了液はスラリー濃度 $5 \mathrm{~g} /$ l 程度の ためシックナに送られる。シックナ OF 夜は第 2 清浄工程へ送ら れ，スピゴットはベルトフィルタで洰過される。洰過ケーキはカ ドミ工場へ送られ，カドミウムが回収される。

シックナ設置当初はOF夜は一旦受槽に貯えて, ポンプで第 2 清浄工程へ送つていたが, 後に省エネルギーのためシックナと第 2 清浄工程間を直接蛹で結んでポンプを廃止した。

（5）第 3 清浄工程残渣の回収 (昭和54年 2 月以降) 第 3 清净工程残渣は $\alpha$ - ニトロソ $\beta$-ナフトールとC。のキレート化 第 4 表 溶解清浄終了液分析値例

\begin{tabular}{|c|c|c|c|c|c|}
\hline & $Z_{n}(8 / 8)$ & $\mathrm{Cu}\left(\omega_{0}\right)$ & $\operatorname{coc}\left(m^{m}\right)$ & $C 0\left(m_{R}^{*}\right)$ & Fer $($ ) \\
\hline 淤解系 & 135 & 280 & 280 & 2.0 & 1.5 \\
\hline 清浄終了液 & 135 & tr & tr & 0.1 & 1.5 \\
\hline
\end{tabular}


合物を主成分とし，他に付着液に起因する亜鉛を含む。

從来この残渣はリパルプして酸性溶解工程へ送つていたため, 业鉛は回収されるが、コバルトは未回収のままであつた。そこで リパルパを洗浄槽に改造し，第 3 清浄残透を水洗して亜鉛分を除 くことによりコバルト品位を上げ，コバルト原料として回収して いる。

（6）要鉛末原単位の低下 清浄工程の亜鉛末原単位は添加 位置の改善, 清浄温度の変更等により逐次低下しつつある。

\section{4. 電解, 溶鋳部門}

電解，溶鋳部門の建設に当つては積極的な機械化を計つた。す なわち, 当時としては, 大型の $1.67 \mathrm{~m}^{2} /$ 枚の有効面積を持つ力 ソード板を採用し，極板搬送システム，剝取機についても大幅な 自動化がなされた。また剥取られた析離两鉛はストックコンベヤ, 電気炉，自動鋳造機，自動パイリング装監と連続的に処理される。

\section{$4 \cdot 1$ 電解工程}

電解工程の特長および改善点を以下に述べる。

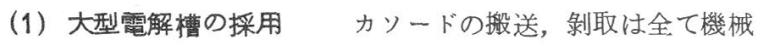
化するため, 極板の大型化が可能となり，しかもトラブルが生じ た場合は, 日本人の体格で運び得る寸法と言うことで $1.67 \mathrm{~m}^{2} /$ 枚のカソード板を採用した。電解槽は 324 槽で 18 槽 / 列 $\times 18$ 列 の配列となつている。通常 2 列は整供のため休転し, 16 列, 288 槽が稼動する。各槽はカソード 33 枚, アノード 34 枚を備え, ウォルカータイプに接続されている。

(2) 電流密度変化操業 シリコン整流器の最大能力は電流 密度 $600 \mathrm{~A} / \mathrm{m}^{2}$ 相当であるが, 安価な夜間電力を積極的に利用す るため昼と夜の電流密度を変化させて操業できるように設計され ている。このため中性液槽としては $600 \mathrm{~m}^{3}$ 槽 4 基を備え, 電解 操業度変化のバッフォとしている。

（3）カソード搬送, 虽取システムカッード引揚げは天井 クレーンにより隣接する 2 列の各槽から 11 枚ずつ同時に引揚げ られ, 一旦移載台車に移された後, 循環ホイストで吊上げて運搬, 途中て温水槽で水洗後, 豩取機へ搬入される。循環ホイストの運 転，水洗操作は無人で行なわれる。

剝取機は自社製で，カソード板の自動搬入，搬出装置および未 剥板の取出し, 新カッード板の供給装置を装えている。剝取られ た析離覀鉛板は自動的にパイリングされた後, ストックコンベヤ で釷造工程の電気炉まで運搬される。

（4）硫酸第一鉄によるアノードクリーニングアノードに 付着したマンガンクラストは硫酸第一鉄でクリーニングされる。 すなわち硫酸第一鉄を尾液で溶解した液中にアノードを浸漬, 加

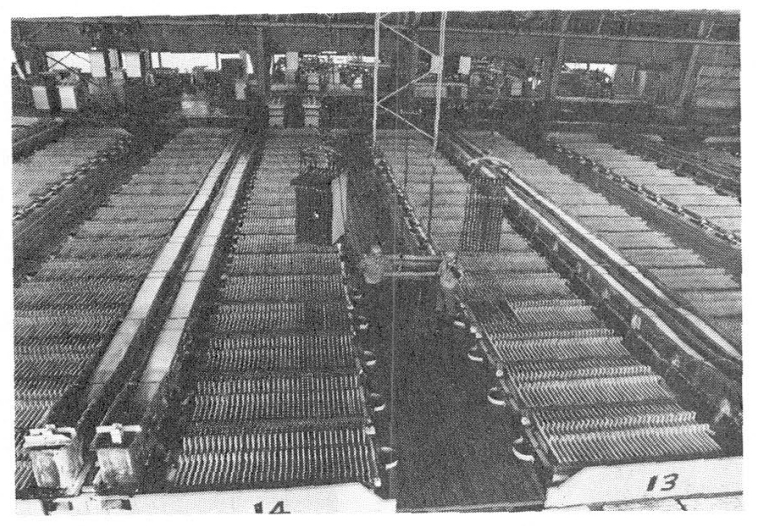

第 5 図 亜鉛 電解 槽
熱しアノード表面の $\mathrm{MnO}_{2}$ を還元, 溶解して除去する。アノード クリーニング終了液は鉄イオンを多量に含むため前述の上うに溶 解工程へ送り加鉄清浄の鉄源とする。

化学的なアノードクリーニング法は, 他の機械的な方法にくら べ過度にアノード表面を傷めることがないためアノードからの鉛 溶出が少なく，から寿命も長い。

（5） TCAクーラの採用電解液泠却用として 13 基のF $\mathrm{R} P$ 製 T C A ターラを備えている。2 基が中性液用で 11 基が循 環液用であり外気温, 電流密度に応じて運転台数が加減される。

（6）カソード研磨機の導入 (昭和51年9月) 従来カッー ドAl 板の研磨はハンドグラインダを用いて手作業で行なつてい たが，自社開発の自動研磨機を導入した。この研磨機は循環ホイ ストのラインの中に, 剥取機に後続するように組込まれ, 剥取り の終つたカッード板の研磨機への搬入, 研磨, 搬出が自動的に行 なわれる。

（7）最近の省エネルギー対策

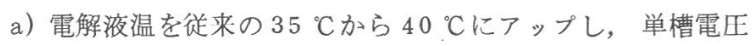
の低下を計つた。同時に T C A クーラの電力消費も低下した。

b）電解液の $\mathrm{H}_{2} \mathrm{SO}_{4}$ 濃度をアップさせて単槽電压の低下を計 つた。同時にデプレッションも高めたため溶解, 清净工程での造 液量が低下し, 動力用電力も低下した。

上述のような省エネルギー対策により大幅な電力原単位低下が 可能となった。

\section{$4 \cdot 2$ 溶鋳工程}

溶融炬としては $880 \mathrm{~kW}$ の低周波誘導炬 2 基を持ち, 各炬に自 動鋳造，パイリング装置 1 セットずつが備わつている。 溶鋳工程の特長および改善点は以下の通りである。

（1）自動筹造, パイリングシステム自社開発のシステム で，電気炉より亜鉛ポンプで服み出された溶融亚鉛は，エンドレ スに䔟動する鋳型に一定量鋳込まれる。渣取機で表面のスカムを 除去した後，水冷凝固させたスラブ亜鉛は 48 枚が 1 ユニット（ 約 $1 \mathrm{t}$ ) となるよう自動的にパイリングされる。

（2）ドロス絞り機電気炬からのドロスはドロス絞り機に かけられて, 溶融メタルが回收される。回收メタルは電気炉へ, また最終ドロスは前述のように哣焼炉へ繰返される。

（3）調合亚鉛の製造（昭和55年 4 月以降）溶骶メッキ用 の調合亜鉛製造設備が完成し, 多様化するユーザーの要求に応じ て各種調合亜鉛の製造を開始した。

設備としてはL P G 燃烧の調合炉, 大型鋳型と鋳造設備からな り, 合金元素の迅速, 正確な分析のためカントレット分析装置を 備えている。

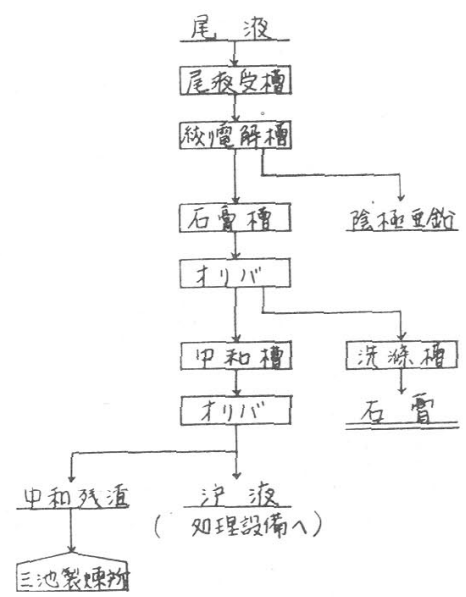

第 6 図

脱 $\mathrm{Mg}$ 設備操業 系統図 


\section{5. 脱 $\mathrm{Mg}$ 設 備}

昭和 45 年の電解工場スタート以来, 電解液中の $\mathrm{Mg}$ は漸次増 増加傾向をたどり, 特に高 $\mathrm{Mg}$ 品位鉣石の供用により昭和 49 年末 には $20 \mathrm{~g} / \mathrm{l}$ 以上に達し, 単槽電圧の上昇等電解成績に重大な悪 影響が出たため臨時的に赤渣洰過設備を利用して尾液の中和, 淊 血を行なつて $\mathrm{Mg}$ 濃度の低下を計つた。その後, 昭和 52 年末に は新しく脱 $\mathrm{Mg}$ 設備が完成し, 高品位 $\mathrm{Mg}$ 鉱石の供用にも十分 耐え得る亚鉛電解工場となつた。

脱 $\mathrm{Mg}$ 設備は絞り電解, 石膏回収, 中和工程の 3 工程からなる。 その操業系統図を第 6 図に示す。

各工程の概要は以下の通りである。

（1）较り電解工程電解工場より一部抜出された尾液は脱

$\mathrm{Mg}$ 設備の絞り電解槽でさらに $\mathrm{Zn} 20 \mathrm{~g} / \mathrm{l}$ まで絞り電解される。

（2）石霥回収工程絞り電解尾液は $\mathrm{H}_{2} \mathrm{SO}_{4} 200 \mathrm{~g} / \ell$ 以上
となるため炭酸カルシウムで遊離 $\mathrm{H}_{2} \mathrm{SO}_{4}$ を中和して石高を回収 する。

（3）中和工程石膏工程から送られた液を消石灰で中和し て水酸化亜鉛を回収する。最終洰夜は排水処理設備へと送られる。

\section{6. 結}

彦島亜鉛電解工場スタート以来の 10 年をふりかえると, 新工 場の建設, 生産量の拡大に努めた前半と, オイルショックに端を 発した低成長の経済状況下で余儀なく減産を強いられ，コストダ ウンに努めた後半に分けられる。

そして今, また第 2 次オイルショックによるエネルギー価格の 高騰に直面し，厳しい道がさらに続くものと予想される。

この大きな試練に耐え抜くべく，さらに一丸となつて省エネル ギー,コストダウンに全力を尽したい。

\section{Zinc Operation at Hikoshima}

by Takakazu TORIGOE

Hikoshima Smelter is situated in Hikoshima Island at the southeast end of Honshu, and faces Northern Kyushu Heavy Industrial Area which is opposite side of Kam-mon Channel.

The Smelter produced zinc by the horizontal retort process since 1915, but the Company decided to replace the horizontal retort plant by an electrolytic plant. Construction of the new electrolytic plant began in July, 1969 and production of electrolytic zinc started in November, 1970.

The new plant adopted a highly-mechanized and fully-automated system, for example, process computer control system, a stripping machine and automated transporting system for zinc cathodes.

Capacity of the plant is $84,000 \mathrm{t} / \mathrm{y}$, but in recent years, unfortunately we have been forced to reduce the production rate, and now we are making efforts to lower the operation cost and save the energy through improvements as follows:

(1) Heat recovery of fluid bed roaster.

(2) Lowering the electric power consumption at the roasting, the leaching, the purification, and the electrolytic stages.

(3) Decreasing zinc dust and other reagent requirement.

(4) Recovery of cobalt from residue at the purification stage.

(5) Feeding of melting furnace dross to the roaster.

\section{〔2-15〕 佐賀関製錬所の鉊製錬}

\section{1. 緒}

\section{言}

最近 10年間の当所の歩みを振返ると前半は経済の順調な伸展に 伴い製品の需要も旺盛であり, 設備能力の増強を図る等払大の一 途を辿り生産量を $2,500 \mathrm{t} /$ 月ときわめて好調に推移した。しかし, 後半特にいわゆる第一次オイルショック以降は, 景気も後退して 減産を余儀なくされるに至り, 設備の効率的な活用を図るべく, 種々検討を加えた結果, 昭和 51 年 4 月以降溶鉱炉系統を休止した。

したがつてそれ以来当所の溶鍊部門は電気炬のみの操業となり, 当所の銅製鍊，三日市の亜鉛製鍊等全社内から産出する半製品類 の一括処理設備としての役割を果している。これにともない電鍊部 門も三日市, 八戸(委託分)等の粗鉛量含みて約 $500 \mathrm{t} /$ 月の電気鉛 の生産にとどまつているが，以下これらの経緯について述べる。

\section{2. 鉛 溶 鍊 部門}

\section{$2 \cdot 1$ 操業概況}

\section{1. 正会員 日本鉱業株式会社佐賀関製鍊所副所長}

$$
\text { 幸俊 竝 }{ }^{1}
$$

最近 10 年間における当所主要設備の変遷と操業の推移を概観す ればつぎのようである。

昭和 45 年 1 月溶鉱炬が改造され設備能力も $3,000 \mathrm{t}$ 粗鉛/月とな り溶鈗炉，電気炉各 1 基で約 $2,500 \mathrm{t}$-粗鉛 /月の生産を継続してき たが, 昭和 51 年操業コスト及び環境面等から溶鉱炉法を見直し， 同年 4 月に溶鉱炉を休止することとなつた。その後は電気炉 1 基 のみによる操業となり, 処理原料も社内発生の鉛含有半製品が主 体となり生産量も $200 \mathrm{t}$ 一粗鉛/月程度となつた。なお, 昭和 53 年 9 月前処理工程の改善による操業の効率化が図られ, 54 年 7 月には 省エネルギーを目的として故鉛炉を鉛電気炉前に統合した。

当所鉛溶鍊部門の主要設備の変遷を第 1 表に, 生産量の推移を 第 2 表，現在の鉛溶鍊操業系統図を第 2 図にそれぞれかかげる。

$2 \cdot 2$ 電気炉操業について

鉛電気炉の原料は所内の銅転炬用コットレルダストおよび社内 外のドロス，鉛涬等である。還元㘊としてはコークスの他，脱As， 脱 S のため鉄を添加する。鉄源としてはスクラップの他に三日市 磁選涬を使用し，この中に含まれる $\mathrm{Cu}, \mathrm{Ag}$ の回収をはかつてい 